\title{
On the Slavic Immigration in the Byzantine Balkans
}

\author{
Johannes Koder
}

The Balkans have a complex ethnic and linguistic structure owing to migrations from the North which took place in waves of varying intensity and changed the regions demographic character from the antiquity onwards, when it was inhabitated by Illyrian and Greek tribes. ${ }^{1}$ The Slavic immigration from the late 6th century onwards was the most important for the present ethnic composition of the populations in southeastern Europe. It has been a matter of great debate since Jacob Philipp Fallmerayer (1790-1861) published his notorious thesis, stating that "not the slightest drop of undiluted Hellenic blood flows in the veins of the Christian population of present-day Greece". ${ }^{2}$

Already since the 12th century Byzantine historians like Nikephoros Bryennios (12th century), George Pachymeres (13th century), Nikephoros Gregoras (14th century), Michael Kritoboulos and especially Laonikos Chalkokondyles (15th century) discussed the ethnic identities of the medieval Balkan populations and their alledged Illyrian origin. They used the ethnonyms Albanoi, Akarnanoi, Bosnoi, Bulgaroi, Dalmatai, Illyrioi, Makedones, Mysoi, Sarmatai, Skythai, Thrakes, Thessaloi and Triballoi. ${ }^{3}$ The collective names of the Slavs,

1 The indigenous Illyrian tribes and their territories are first mentioned by Hekataios of Miletos (d. ca. 476 в.C.), fragments $86,97,100,119,172$.

2 Fallmerayer, Geschichte der Halbinsel Morea, p. III (Vorrede): "Das Geschlecht der Hellenen ist in Europa ausgerottet. Schönheit der Körper, Sonnenflug des Geistes, Ebenmaß und Einfalt der Sitte, Kunst, Rennbahn, Stadt, Dorf, Säulenpracht und Tempel, ja sogar der Name ist von der Oberfläche des griechischen Kontinents verschwunden ... auch nicht ein Tropfen echten und ungemischten Hellenenblutes in den Adern der christlichen Bevölkerung des heutigen Griechenlands fließet" (The race of the Hellenes has been wiped out in Europe. Physical beauty, intellectual brilliance, innate harmony and simplicity, art, competition, city, village, the splendour of column and temple-indeed, even the name has disappeared from the surface of the Greek continent .... Not the slightest drop of undiluted Hellenic blood flows in the veins of the Christian population of present-day Greece). This thesis was questioned already by Miklosich, Die slavischen Elemente - Gerhard Neweklowsky (Klagenfurt / Vienna) kindly drew my attention to this valuable early study. For a well-balanced assessment see now Schreiner, "An den Anfängen"; for bibliographical information: Grünbart, $J a$ kob Philipp Fallmerayer.

3 Koder, "Illyrikon und Illyrios".

(C) JOHANNES KODER, 2020 | DOI:10.1163/9789004425613_004

This is an open access chapter distributed under the terms of the CC BY-NC 4.o License 
namely Sklaboi, Sthlaboi, Sthlabenoi, Sklabenoi, Antai, Ouenedai etc. ${ }^{4}$ which are well documented in the early medieval sources, are missing from this list, probably because they were not in use in the later centuries.

In the present, the mainstream view is that Slavic tribes had their first contacts with the eastern Roman empire in the mid-6th century at the latest, during the reign of the Byzantine emperor Justinian I (527-565) and that their first major phase of immigration to south-eastern Europe began a few years after this emperor's death. ${ }^{5}$ Moreover, their place of origin is considered to have been in the north - Heinrich Kunstmann's theory that the Balkans were the original homeland of the Slavic tribes and that they migrated from there to the north has been dismissed. ${ }^{6}$

Our information about the Slavic immigration and integration ${ }^{7}$ is based in part on written sources: hagiographical texts, for example the Miracula Sancti Demetrii and the Vita of Nikon Metanoeite, historians beginning with Jordanes and Procopius, chronicles, especially the Chronicle of Monemvasia, ${ }^{8}$ and imperial handbooks, like Ps.-Mauricius' Strategikon or the Taktika, which are ascribed to the emperor Leo vi the so-called Wise, and finally the works of Constantine Porphyrogenitus, the De thematibus, and mainly the De administrando imperio, a Vademecum for his son Romanus. Furthermore, archaeological remains and toponyms or placenames enable us to reconstruct the immigration of the Slavic settlers. ${ }^{9}$

The Byzantine territories in the Balkans have clear boundaries to the west, south and east, namely the Adriatic, Ionian, Aegean and Black Sea. To the north, the lower valleys of Sava and Danube mark the administrative and political frontier in the early Byzantine period, with Sirmium (Srmska Mitrovica), the capital of Illyricum, being its northernmost fortified city. The linguistic separation between Greek and Latin runs, according to the evidence of late

4 Not Slaboi, because Greek phonotactic does not allow $\sigma \lambda$ - in initial position: Brugmann/Delbrück, Grundriß, p. 749-750. For the collective names see Weiss, Das Ethnikon Sklabenoi; Koder, "Anmerkungen zum Slaven-Namen".

5 For a critical approach to this mainstream view, see the chapter by Florin Curta in this volume.

6 Kunstmann, Die Slaven, but see Schramm, Ein Damm bricht, pp. 175-208 (arguing on the tribal names); Curta, The Making of the Slavs; Koder, "Anmerkungen zum Slaven-Namen".

7 Useful overviews: Ivanov, "Byzantium and the Slavs"; Pahlitzsch, "Byzanz", pp. 94-97; Hardt, "Slawen”, pp. 171-174; Izdebski, "The Slavs' political institutions”; Nystazopulu-Pelekidu,

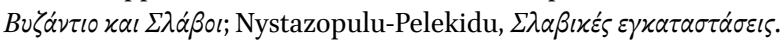

8 Kislinger, Regionalgeschichte; Anagnostakis/Kaldellis, "The Textual Sources" (with a reference to Pausanias as a source for Arethas of Kaisareia); see also Kresten, "Zur Echtheit des sigillion"; Koder, "Arethas".

9 The sources will be discussed below. 
antique inscriptions, along a virtual line extending from Dyrrachion (Durres) Skopia - Serdika (Sofia) - Nikopolis (Weliko Tarnowo) to the estuaries of the Danube; 10 it is too narrow.

Similar to the migration and settlement of the so-called "Protobulgarians", the first organized groups of "southern" Slavs reached the Balkans at different places along the Danube frontier about the year 574 . The first wave moved under the military and political rule of the Avars who captured Sirmium (Srmska Mitrovica), Singidunum (Belgrade) and Viminacium (Kostulac) in the year $582 .{ }^{11}$

The anonymous text of a short prayer, written on a roof-tile during the siege of Sirmium, illustrates the desperate situation in the city which had been the capital of the Praetorian prefecture of Illyricum from 318 until its occupation by the Huns in 441 and again from 567 onwards. The prayer reads: "Oh Lord, help the town and halt the Avar and protect the Romania and the scribe. Amen". ${ }^{12}$ This short sgraffito in writen in the vernacular demonstrates vividly how evident the leading role of the Avars during the first phase of the Slavic immigration must have been that the contemporary eyewitnes mentioned only them, even if in reality they crossed along with the Slavs. ${ }^{13}$ One explanation for the latter's subordination to the Avars may be that their political structure, which Procopius described with the term demokratia, ${ }^{14}$ impeded coordinated military resistance against the enemy.

After the capture of Sirmium, the Byzantines reacted to the new status quo by transferring not only the centers of administration to the south, but also the worship of the warrior-saint Demetrius from Sirmium to Thessalonica. ${ }^{15}$ His two early collections of "miracles" are important sources for the early history of the Slavs in the Balkans. ${ }^{16}$ They are dated before 620 and after 680, respectively, and were written during and after the process of political separation from the Avars of those Slavic tribes who after 582 migrated southwards. They

\footnotetext{
10 Gerov, "Die lateinisch-griechische Sprachgrenze".

11 Pohl, Die Awaren, pp. $5^{8-76 .}$

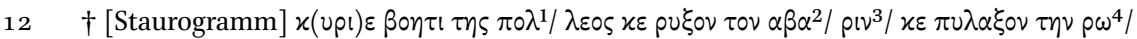
$\mu \alpha v i \alpha \nu^{5} / x \varepsilon \tau \sigma \nu \gamma \rho^{6} / \alpha \psi \alpha \nu^{7} / \tau \alpha^{8} / \alpha \mu \eta^{9} / \nu \dagger^{10} /$, Noll, "Ein Ziegel", 145-148. - Probably the piece is authentic; see Koder, "Anmerkungen zum Awaren-Sgraffito",

13 Pohl, Die Awaren, pp. 99-121.

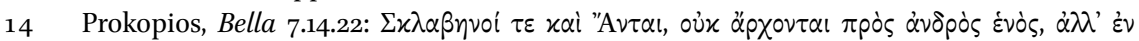

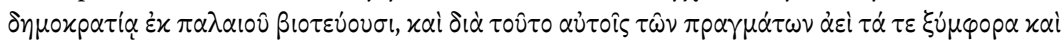

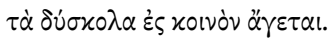

15 Bauer, Eine Stadt und ihr Patron, pp. 235-281.

16 Miracula Demetrii, see Koder, "Anmerkungen zu den Miracula".
} 
reached Macedonia where some tribes settled in the immediate neighbourhood of Thessalonica, whilst others made their way to Thessaly and Epirus.

According to the first two tales of the second collection of the miracles, some of these tribes with their leader Chatzon revolted around the year $615 \cdot{ }^{17}$ The tales maintain that they devastated not only the neighbouring provinces of Thessaly and Epirus, but "all" of Greece, the islands and even parts of western Asia Minor - probably an exaggeration. When Chatzon decided to lay siege on Thessalonica itself, he invited the Avars to join him who accepted the call. It goes without saying that Saint Demetrius saved his city, though only after a siege of 33 days. ${ }^{18}$ Howecer, it is interesting that in the first two decades of the 7 th century - that is, before the unssuccessful attack against Constantinople by the cooperating armies of Persians and Avars in 626 - these tribes were already independent from the Avars (whose political center was in distant Pannonia), even though they still recognized their political supremacy. Only after 626 , as a result of their defeat at Constantinople, the prestige and influence of the Avar leaders declined in the east.

At this time, the Slavic tribes continued their infiltration in Greece. They settled in southern Epirus, Macedonia, and Thessaly, and reached even at the southernmost parts of the Peloponnesian peninsula. Although in some regions the indigenous inhabitants were expelled by force, the settlement of the Slavs in the central and southern parts of Albania, in Macedonia and in Greece did not meet considerable resistance. ${ }^{19}$ This may be explained in part with the low level of Byzantine military presence in the mainland and the western areas of the peninsula, because the imperial armies were concentrated along the eastern coastline and the islands of the Aegean and the Ionian Sea. However, an important reason for this quasi effortless immigration was the significant demographic decline of the indigenous population, which had been caused by the so-called Justinianic plague, the pandemic pestilence that spread across the eastern Mediterranean in consecutive waves from the year 541 until the mid-8th century.

The second source of information is archaeology. Remains of monuments and nearly all kinds of small findings allow for the partial reconstruction of settlement history on the local level. Furthermore, it seems that the Slavs introduced more resistant types of cereals, for example millet, ${ }^{20}$ as well as new or modified agricultural tools which were better suited for the mountainous

17 Miracula Demetrii, $\S$ 193-214.

18 Pohl, Die Awaren, pp. 102-105.

19 Pohl, Die Awaren, pp. 107-112.

20 Millet (kenchros) is mentioned in Maurikios, Strategikon 11.4 and in Leo vi, Taktika 18.99. 
landscape of the mainland. This has been interpreted as evidence of their swift settlement as sedentary farmers in the newly occupied regions. ${ }^{21}$ For certain groups of small findings, in particular pottery findings, their Slavic or AvaroSlavic origin is a matter of debate not only due to the refinement of archaeological research methods, but also for reasons of national politics related to the national histories and identities of the Balkan region, to which I referred in the beginning of my paper. This applies to the Peloponnese, for example, where we have some 300 sites with thousands of findings between the 4th to the 8th century, the exact date and interpretation of which is still disputed. ${ }^{22}$

A valuable group of sources are the already mentioned toponyms the semantic typology of which offers information about the landscapes the Slavs were confronted with: e.g. balta, baltos (marsh, moor), ezeros, nezeros (lake), Goritsa (mountain peak), Kamenikos (stony peak), lanka, lankadi (ravine), Zagora (behind the mountain or woods). Furthermore, they also serve as a possible indicator for the proportion between the new settlers and the indigenous population. Even though it is a difficult or even an impossible task to reconstruct the regional Slavic microtoponyms in medieval Greece, at least the Slavic names of settlements have been documented insofar as they have survived or have existed in the last two centuries in situ. Our knowledge relies often on travelogues, on early modern times descriptions of Greece, and on maps which were produced soon after the foundation of the modern Greek state, that is, before the policy of Hellenization of non-hellenic toponyms was systematically implemented. ${ }^{23}$ The book of Max Vasmer represents a landmark in this regard, whereas the recently published etymological lexicon of Greek toponyms by Charalampos Symeonides is of extraordinary importance as well. ${ }^{24}$ The research on Slavic placenames in the Byzantine Balkans, especially in Greece, owes much to the research of Jordan Zaimov, Demetrios

21 See Henning, "Untersuchungen zur Entwicklung der Landwirtschaft”; Henning, Südosteuropa zwischen Antike und Mittelalter; Henning, "Eisenverarbeitungswerkstätten".

22 See Avramea, Le Péloponnèse, pp. 163-203 and map; Lampropoulou/Anagnostakis/Konti/ Panopoulou, " $\Sigma u \mu \beta>\lambda \eta \eta$ "; see also the discussion in Kislinger, Regionalgeschichte, pp. 72-

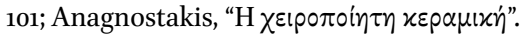

23 The most important is the French military map: Carte de la Grèce redigée et gravée au dépôt de la guerre d'après la triangulation et les levés exécutés par les officiers du corps d'état majeur à l'echelle de 1:200.0oo, Paris ${ }^{2} 1852$; see also H. Kiepert/J. Kokides, General-Karte des Königreiches Griechenland im Maße 1:300.ooo, Vienna 1885, and the Sonderausgabe VII andX, 1940, 1:100.000 (German Wehrmacht), relying on Greek state maps produced in the 30 of the 2oth c.

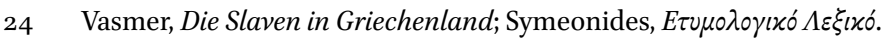


Georgacas, Phaidon Malingoudis, François Brunet, Gottfried Schramm, and Peter Soustal. ${ }^{25}$

Loans from the common Slavic language are often attested in the Greekspeaking parts of the Balkans during the Byzantine and the post-Byzantine period. ${ }^{26}$ For the purpose of the current paper, the etymology of Slavic toponyms and settlement names are of particular interest, insofar as their archaic character may testify to an early colonization. ${ }^{27}$ Significant are names, in which the Slavic nasal vowels ${ }^{*} e$ und ${ }^{*} q$ appear in Greek as $\varepsilon v / \varepsilon \mu$ and $o v / o \mu$ respectively ${ }^{28}$ (e.g. Englenoba, Longos, Mesolongi); furthermore, names that did not undergo the metathesis of liquid consonants (e.g. Balta, Gardiki, Gabroba, Kapernikion), a development which may probably be dated before the gth century, or the vowel shift $a>o$ (e.g. Arachova, Dragoboutzista, Kalovo, Prablaka) before the 1oth century. ${ }^{29}$

The number and density of Slavic names of settlements in central and southern Greece allow for an approximate reconstruction of Slavic immigration and settlement patterns. ${ }^{30}$ The following maps rely on Max Vasmer's compendium. ${ }^{31}$ The first map (Map 3.1) shows the number of settlements with Slavic names per ninth of a quadrangle (which corresponds in these latitudes to about 1,00o $\mathrm{km}^{2}$ ). The number of Slavic toponyms per quadrangle varies between zero and 14 in the plains and along the coasts of Greece, and between 20 and 35 in the mountainous landscapes, with one extreme value of $5^{\circ}$ in the region of the southern Pindos (in Epirus).

The comparison with the number of modern settlements, taken from the directory of municipalities of the National Statistic Service of Greece, does not

25 Zaimov, Zaselvane na bălgarskite Slavjani; Georgacas, Place names; Malingoudis, Studien

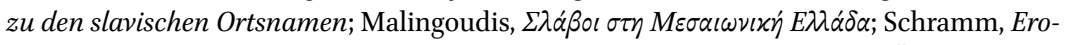
berer und Eingesessene; Schramm, Ortsnamen und Lehnwörter; Soustal, "Überlegungen zur Rolle der Toponyme"; ibid, "Place names", both with more bibliography. Helpful is also Skach, Die Lautgeschichte des frühen Slavischen.

26 See Skach, Die Lautgeschichte des frühen Slavischen, esp. the results pp. 261-265 and 276; see also Holzer, Historische Grammatik des Kroatischen, both with further bibliography.

27 Shevelov, A Prehistory of Slavic; Brunet, "Sur l'hellénisation des toponymes slaves"; Carlton, Introduction to the phonological history; Holzer, "Die Einheitlichkeit des Slavischen".

28 I owe this information to Gerhard Neweklowsky (Klagenfurt/Vienna).

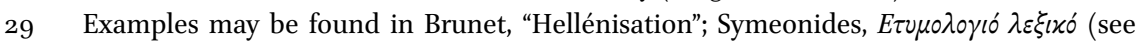
esp. pp. 101-107 and the indexes of Slavic toponyms, pp. 1891-1926); Vasmer, Slaven in Griechenland (Wortregister, pp. 331-50).

$30 \quad$ See Koder. "Zur Frage der slavischen Siedlungsgebiete"; ibid., "Про $\beta \lambda \eta \dot{\mu} \mu \alpha \alpha$ ".

31 Vasmer, Slawen in Griechenland; see also Henrich, "Einige slawische Siedlungsnamen". Lefort, "Toponymie et anthroponymie”; Koder, "Zur Frage der slavischen Siedlungsgebiete". 


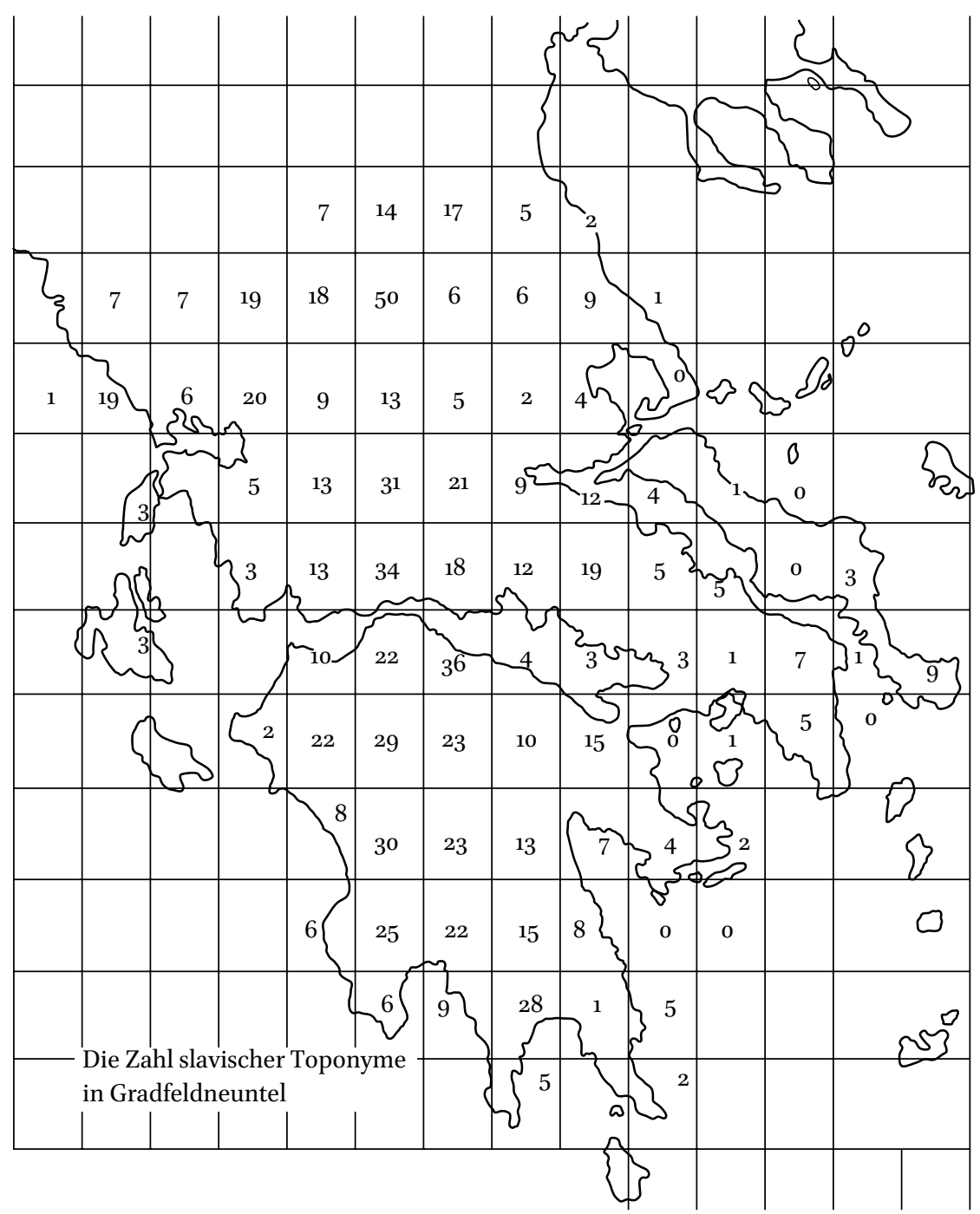

MAP 3.1 Number of Slavic settlement names per ca. $1000 \mathrm{~km}^{2}$ in central and southern Greece MAP CREATED BY J. KODER, 2001

change that picture. ${ }^{32}$ It makes the contrasts even clearer. The second map (Map 3.2) shows the percentage of Slavic settlements in the total number of settlements in the mid-2oth century.

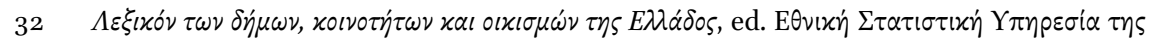

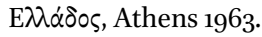




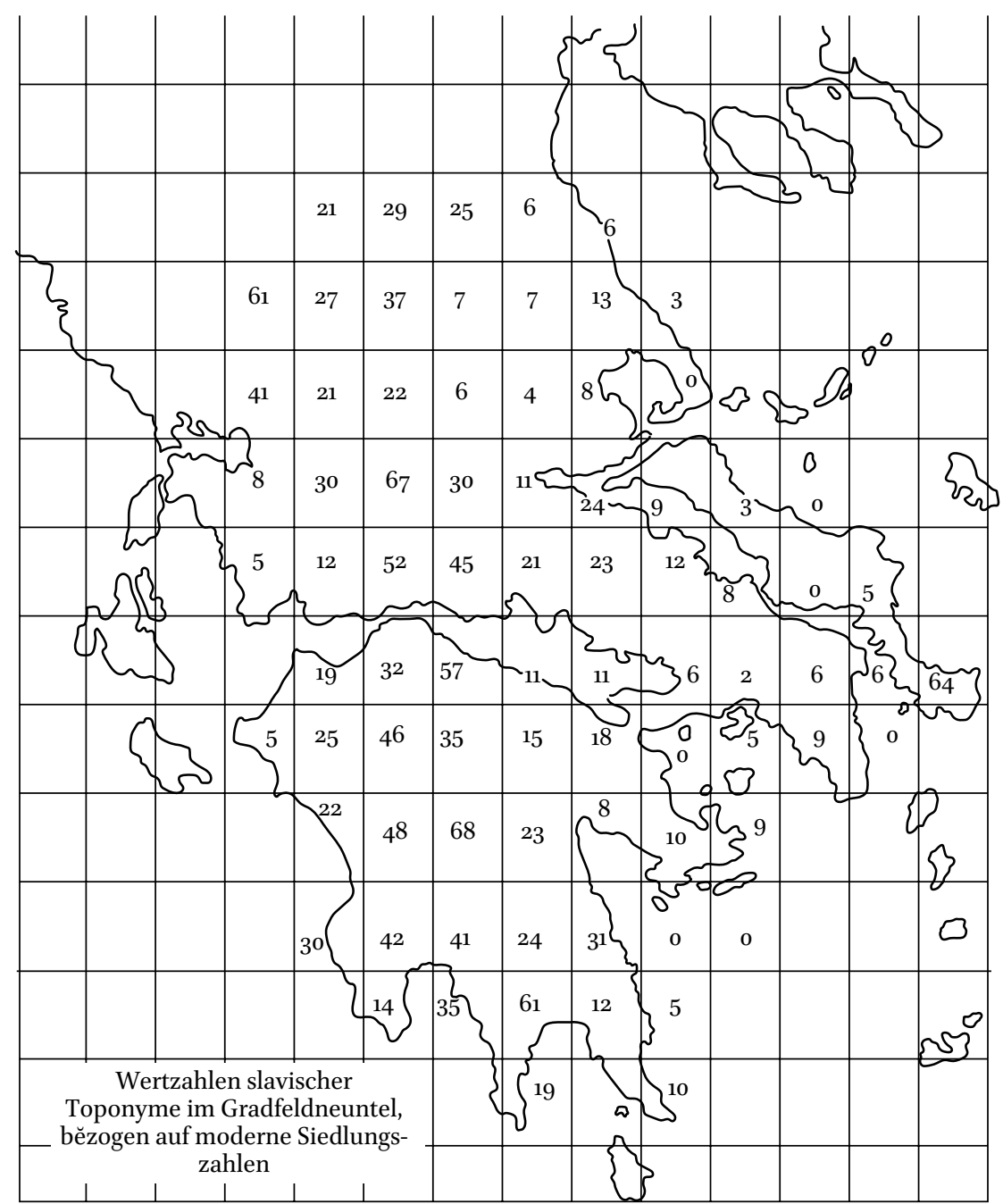

MAP 3.2 Relation in \% of the Slavic and the total of modern settlement names in central and southern Greece

MAP CREATED BY J. KODER, 2001

From the toponymic patterns, it can be deduced that the early medieval Slavic settlement in the major parts of Greece took mainly place in the inland, often along the mountain ranges. ${ }^{33}$ The Slavs proceeded to the south from both sides of the Pindos mountain range and the mountains in Aitoloakarnania

33 For the development of the Byzantine reconquista of territories occupied by the Slavs and their integration see Chrysos, "Settlements of Slavs", with bibliography. 
(Panaitolikon, Arakynthos, Xeromera). They crossed the gulf of Corinth at its narrow western part - not at the Isthmos, since the fort and the city of Corinth were always under Byzantine military control - and they proceeded to settle on the mountain massifs of the Peloponnese (Panachaikon, Erymanthos, Minthe, Lykaion, Mainalon, Ithome, Taygetos, Parthenion, Parnon) as far as the Maina peninsula.

In the Aegean coastal areas, the density of Slavic settlements is significantly lower, especially in the plains of Attica and Boeotia and on the island of Euboea. In this context, it should be noted that the Boeotian urban center of Thebes was the capital of Byzantine administration in the medieval province Hellas, with the nearby coastal city of Euripos (ancient Chalkis) functioning as its military harbour.

On the other hand, the northern and northwestern Greek regions, Macedonia and Epirus vetus, demonstrate an overall high density of Slavic toponyms in the plains and even on the coastlines. This corresponds with the information of the written sources, as shown, for example, from the toponymic evidence for the Chalkidike peninsula and the adjacent part of eastern Macedonia, ${ }^{34}$ for which a study on the linguistic development of the toponyms was published some thirty years ago. ${ }^{35}$ The fact that, apart from the names of (former) Slavic monasteries, old Slavic placenames are also found in the peninsula of Mount Athos to the south of Hierissos is an additional argument for an early immigration before the gth century, when the foundations of large Athonitic monasteries began. ${ }^{36}$

The majority of early Slavic settlements consisted of villages which in the course of the peninsula's reconquest by the Byzantines were subordinated to a Byzantine fortified town which functioned as administrative, ecclesiastic, and economic center. A good example is the Dropuli valley in Epirus in southern Albania (Map 3.3): Along the river Drino, three centers of agriculture and market existed during the Roman and the early Byzantine period: Antigoneia, Hadrianupolis and a Roman military camp, whose remains nowadays have the place-name Palokastra ("ancient fortification"). The Slavs replaced these abandoned centers with more than forty small villages on the mountain slopes at both sides on the level of the water horizon. The modern regional capital Gjirokastra (Argyrokastron) was founded only after the reconquest of the area by Emperor Basil II (976-1025) as the valley's fortified urban center. ${ }^{37}$

34 See the map in Lefort, "Toponymie et anthroponymie", fig. 1.

35 Brunet, "Hellénisation".

36 Soustal, "Zur Präsenz der Slawen".

37 Soustal, Nikopolis und Kephallenia, pp. 50-54; Koder, "Про $\beta \lambda \eta \dot{\mu} \mu \tau \alpha$ ". 


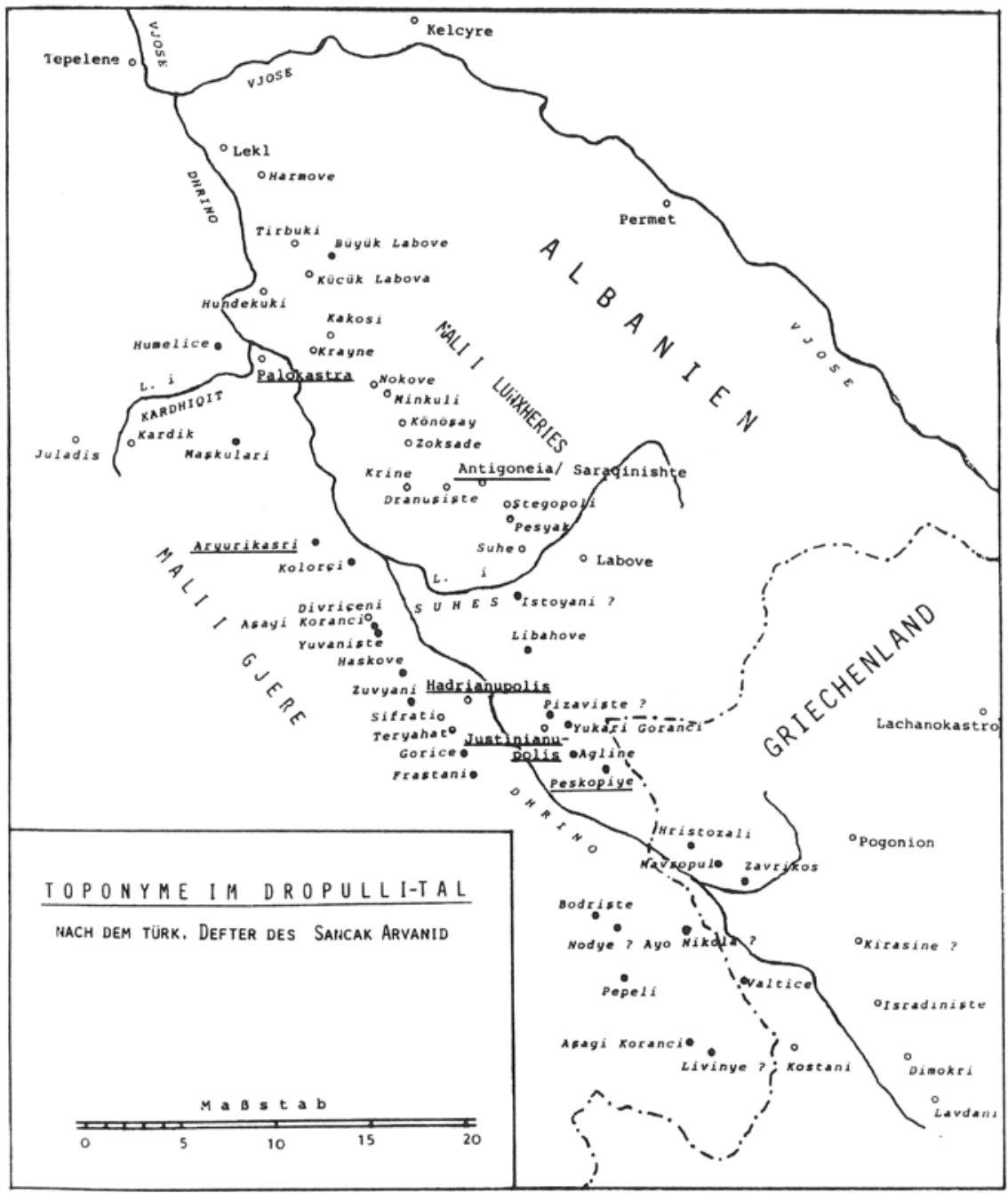

MAP 3.3 Toponyms in Dropulli

MAP CREATED BY J. KODER, 2001

Slavic villages in close proximity to, or even as suburbs of, Byzantine cities are documented often in written sources only after the 8th century, although they probably existed much earlier. Interesting examples are two central towns, the harbour city of Patras in northwestern Peloponnese and Sparta in the center of the peninsula.

During the reign of the Emperor Nicephorus I (802-811), the city of Patras survived the attacks of an Arab fleet and of Slavic tribes, who settled in its 
hinterland after having expelled the local population. ${ }^{38}$ According to a religious tradition, the city's patron saint, apostle Andrew, saved it from the attackers, acquiring the role of an hypermachos strategos (defending general) for Patras, like St Demetrius for Thessalonica and the Mother of God for Constantinople. ${ }^{39}$ As a thanksgiving offering to St Andrew for his miraculous help, the emperor devoted the Slavic tribes and their land in the region of Patras to the saint's metropolitan church. ${ }^{40}$ In view of this historical background, it is not surprising that around Patras and in its hinterland more than 8o Slavic toponyms are documented.

The testament (diatheke) of the holy monk Nikon Metanoeite (ca. 930-ca. 1000 ) is a valuable source for the city of Sparta. ${ }^{41}$ It reports on the miracles performed by the saint in favour of Lakedaimona, the name of Sparta in the 1oth century. Greeks and Jews lived in the city, with the saint odrering that the latter had to be expelled, whereas the Slavs had settled in close proximity to it in a separate village named Sklabochori (Slavic village). It is not clear whether these were subordinate to the bishop of Lakedaimona. ${ }^{42}$ Around Sparta and in its mountainous hinterland, far away from the coast, more than 100 Slavic toponyms are documented.

On the other hand, the eastern coastal regions were obviously much less overrun by Slavic invaders. Two cities there provide proof of Byzantine continuity: Corinth remained unborken under Byzantine authority, as already mentioned above. Hence, in its hinterland only 15 Slavic toponyms are documented. Moreover, the harbour-city of Monemvasia (a name meaning "only one entrance") points to the reaction of the Byzantine government to the immigration, for it was founded as a byzantine stronghold on a rock island close to the southeastern coast at the end of the 6th century. ${ }^{43}$ Consequently, only eight Slavic toponyms are documented in its hinterland, whereas in nearby Mes-

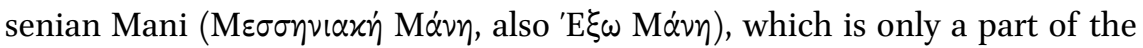
peninsula, more than 200 Slavic fieldnames existed. ${ }^{44}$

After the immigration and settlement of the Slavic tribes, the level of their political organization remained generally low. This made it easier for the

$38 \quad$ Kislinger, Regionalgeschichte, pp. $42-53$.

39 Constantine Porphyrogenitus, DAI 49, l. 25-38.

40 Constantine Porphyrogenitus, DAI 49, esp. l. 50-59; Kresten, "Zur Echtheit des sigillion".

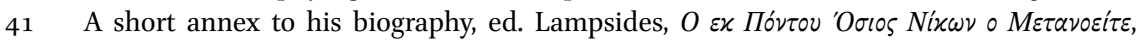
pp. $251-256$.

$42 \quad$ Notitiae episcopatuum, Not. 7.550, 9.411, 10.493, s. also p. 499b.

43 Kislinger, Regionalgeschichte, pp. 29-37; Schreiner, "Note sur la fondation de Monemvasie".

44 Malingoudis, Studien zu den slavischen Ortsnamen. 
Byzantines to regain control over parts of Macedonia and Epirus and most of the territories to the south by the late-8th and early-9th centuries. Obviously, the majority of the Slavic population was not expelled, but stayed as a sedentary rural population (whereas the Romance-speaking Vlachs remained seminomadic livestock breeders). Fortified harbour cities, like Thessalonica, Euripos, Corinth, Patras, and Monemvasia, played an important role in the process of reconquest. They served as nuclei for the later installation of the administrative system of the so-called themata, a type of provinces with combined military and civilian administration. ${ }^{45}$ The Melingues, a tribe in the mountain ranges of Taygetos and Oitylos in the Peloponnese, were distinguishable by their language from the local Greeks and maintained a semi-autonomous regional status until the $15^{\text {th }}$ century. ${ }^{46}$ This probably applies to other tribes as well in remoted parts of southern Greece.

How did the integration of the Slavic population into the Byzantine state work? Information comes from the military manual Taktika of emperor Leo VI who describes, how his father, Emperor Basil I (867-886), brought about the political and religious integration of Slavic tribes in the 6os of the 9th century. According to Leo, this was a process cosisting of three intertwined actions: ${ }^{47}$

First, he persuaded the Slavs to abandon their traditional customs (archaia ethe) and "made them Greek" (grecizised them). I understand the latter measure as a process of adaptation of the immigrants to the usages and manners of conduct of the Greek-speaking population living in Greece, Epirus, and Macedonia. Practically, I think, this included also a basic knowledge of the Greek language. The Emperor Leo did not use the verb hellenize on purpose because this term would point to a higher education and bore still connotations of paganism. ${ }^{48}$

The emperor's second action was to integrate them into the political and military structures of the Byzantine administration by gaving them archontes (rulers, chieftains) according to the Roman model. This often included the

45 Stavridou-Zafraka, "Slav Invasions".

46 Bon, La Morée franque, pp. 498, 505; Ahrweiler-Glykatzi, "Une inscription méconnue"; Malingoudis, Studien zu slavischen Ortsnamen, p. 20.

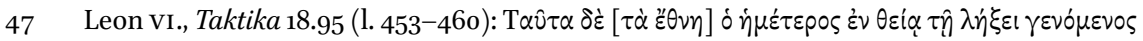

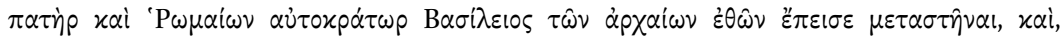

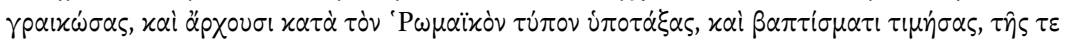

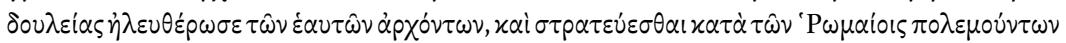

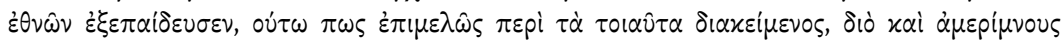

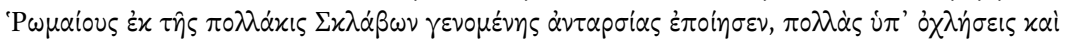

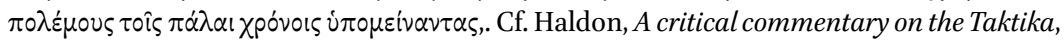
p. 350.

48 Koder, "Anmerkungen zu rpaıxów". 
conversion to Christian faith ("He graced them with baptism"). This is a good example showcasing the well-known close connection of politics and mission in Byzantium. ${ }^{49}$

As a third step, he enrolled them into the Byzantine armies and trained them to fight against all enemies of the empire, which may have included other Slavic tribes as well. The final sentence of the excerpt not only praises the late emperor's policies, but confirms that former problems or difficulties caused by Slavic revolts against the empire were now solved.

Although Leo claims that his father employed this policy of pacification and political integration, Leo's son, Constantine Porphyrogenitus, states that Slavic tribal archontes (chieftains) authorized by the Byzantines already existed since the 8th century: These archontes are mentioned several times in the eight chapters (Chapter 29-36) of his treatise De administrando imperio, which are devoted to the Slavs. Constantine uses once the term sklabarchontes, obviously meaning "Slave-chieftain". 50

There is no doubt that Constantine had read his father's Taktika, especially the chapters on the Slavs, where he found Leo's hapax legomenon verb ypaixów ("grecisize"), because in the chapter on the Peloponnese in his other treatise, the De thematibus, he created and used two times the corresponding verb $\sigma \theta \lambda \alpha \beta \beta^{\prime} \omega$ ("slavicize"), another hapax legomenon. ${ }^{51}$

49 See Beck, Christliche Mission und politische Propaganda; Engelhardt, Mission und Politik; Hannick, "Die byzantinischen Missionen"; Brandes, "Taufe und soziale Inklusion". On the christianization of the Slavs, see Waldmüller, Die ersten Begegnungen der Slawen; Dvorník, Byzantine missions, pp. 1-48 and 230-258.

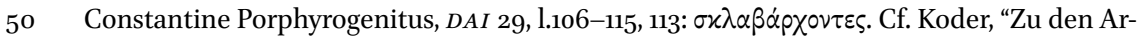
chontes der Slaven".

$5^{1}$ The first mention is in the context of the epidemic plague in the mid-8th century: "all the country was slavicized and became barbaric"; a few lines later he quotes a "well-known

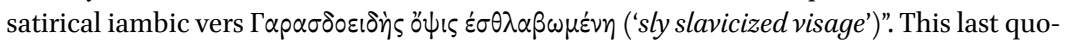
tation, a satirical verse which is ascribed to the grammarian Euphemios, demonstrates not only an aversion to a certain person, but also that Constantine's feeling about the Slavs were not unreservedly positive. Cf. the Greek text in Constantine Porphyrogenitus,

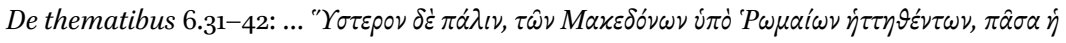

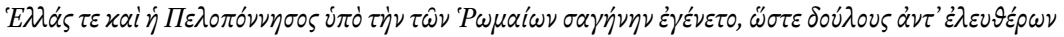

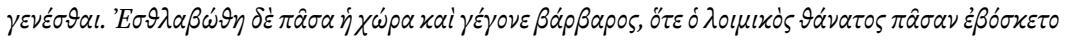

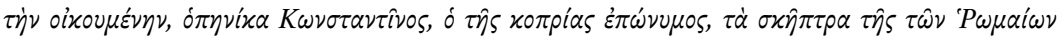

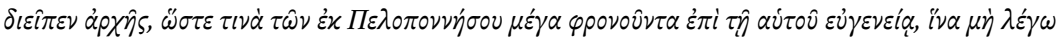

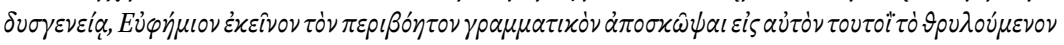

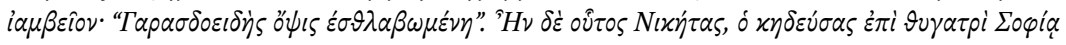

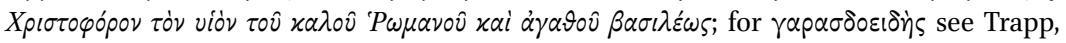
Lexikon, p. 309a. According to the Thesaurus Linguae Graecae (11.1.2014) these are the only testimonies for the verb $\sigma \theta \lambda \alpha \beta \delta^{\prime} \omega$ / $\sigma x \lambda \alpha \beta \sigma^{\prime} \omega$ (in the late Byzantine period always with the 
The above described policy of integration was employed with remarkable flexibility within and beyond the Byzantine political boundaries in the Balkans. It influenced and helped shape the new Slavic states and the so-called Sklabiniai (the Slavic territories inside the state) as well. ${ }^{52}$

A special case were the Bulgarians who already in 681 achieved their territorial and political independence from Byzantium. ${ }^{53} \mathrm{~A}$ treaty between the Emperor Michael III (842-867) and the Tsar Boris-Michael, his godson, in 864 set in motion their conversion, as a top-down Christianization process. On this occasion, the policy described by Leo VI was modified insofar as the Bulgarians were not "grecizised", but kept their own language in the liturgy and in all ecclesiastical matters. This practice would be in use for all the subsequent orthodox missionary activities in Slavic lands outside the borders of the Byzantine empire.

The Byzantine policy in Bulgaria facilitated the ethnic mingling of ThracoMacedonians and Slavs with the "Protobulgarians" who had the role of the ruling class in the first Bulgarian state. ${ }^{54}$ Perhaps, the Paulician and Bogomil movements, which spread in Bulgaria since the late gth and the mid-1oth century, respectively, should be understood - independently from their religious implications - as a political opposition against an approach to a Roman and orthodox Christian identity. ${ }^{55}$ Furthermore, it was not by chance that the Bulgarian rulers adopted the fundamentals of "Roman" political ideology. Consequently, their Tsar Symeon (893-927) tried to usurp the privileges, which the Byzantines had inherited, and even the imperial throne itlself in Constantinople a unique incident before the Crusades. It was only after Symeon's death that his son and successor, Tsar Peter I (927-969), renewed peaceful relations with Byzantuim in 927. In response to that, Emperor Romanos I Lakapenos (920-944) hounored the Bulgarian ambassador in Constantinople with the high rank of patrikios which provided him with the privilege to seat next to the emperor at his table. ${ }^{56}$ It is understandable that Constantine Porphyrogenitus, not a friend

sense of "making / being slave"); see, also, Anagnostakis/Kaldellis, "Sources for the Peloponnese", 130.

$5^{2} \quad$ Vgl. Koder, "Sklavinien".

53 Hannick, "Die byzantinischen Missionen"; Koder, "Nationwerdung”; Koder, "Bulgarische und byzantinische Identität", with further bibliography.

54 This procedure did not include the Vlachs, though they had close relations to the Bulgarians.

55 Lemerle, L'histoire des Pauliciens; Manselli, "Bogomilen" (with bibliography); Browning, Byzantium and Bulgaria, pp. 45-58.

56 See the - angry - description of the bishop Liudprand on the occasion of his visit to Constantinople as ambassador of Otto the Great (June, 4-October, 2, 968), when he had only the 15th position, after the Bulgarorum nuntium, Ungarico more tonsum, aenea catena cinctum, Liudprand, Legatio, Chapter 11, 13 und 19. 
of Lakapenos, disliked the Bulgarians, calling them "the God-hated Bulgarian nation" 57 and "always vain boasters". 58

In concluding, it is evident that all measures and activities, aimed at the integration and subordination of the Slavs and the Bulgarians - and other peoples as well as - to the political and religious sphere of Constantinople, were in principle undertaken by the Byzantine emperors, ${ }^{59}$ even though some patriarchs tried to claim an exclusive right to the organization of missionary activity for the Church - Patriarch Photios $(858-867,878-886)$ being the most prominent case among them. ${ }^{60}$ The aforementioned political practices of integration were successful due to their flexibility and apparent liberality which gave the relevant ethnic groups or states and their leaders the impression that, even after their submission to the Byzantine system of political and ecclesiastical authority, they were free to make their own decisions and that they would maintain their collective identity.

\section{Bibliography}

\section{Primary Sources}

Hekataios of Miletos, Die Fragmente der griechischen Historiker, 1, ed. F. Jacoby, Leiden 1923 .

Konstantinos Porphyrogennetos, De administrando imperio (DAI), ed. Gy. Moravcsik, Washington, D.C. 1967.

Konstantinos Porphyrogennetos, De thematibus, ed. A. Pertusi, Città del Vaticano $195^{2}$. Leo VI, Taktika, ed. G.T. Dennis, Washington, D.C. 2010.

Liudprandi opera, Legatio, ed. J. Becker, Hannover/Leipzig 1915, pp. 535-541.

Maurikios, Strategikon, ed. G.T. Dennis, Vienna 1981.

Miracula Sancti Demetrii, ed. P. Lemerle, Les plus anciens recueils des miracles de saint Démétrius et la pénétration des Slaves dans les Balkans, I, Paris 1979.

Notitiae episcopatuum ecclesiae Constantinopolitanae, ed. J. Darrouzès, Paris 1981.

Vita Basilii, ed. I. Ševčenko, Theophanis Continuati Chronographia quae Theophanis

Continuati nomine fertur Liber quo Vita Basilii Imperatoris amplectitur, Berlin 2011.

57 Constantine Porphyrogenitus, De thematibus, Europe 1, p. 25: हैं $\theta$ vos.

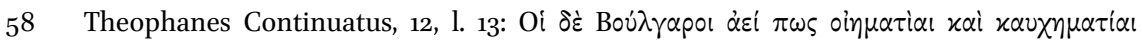

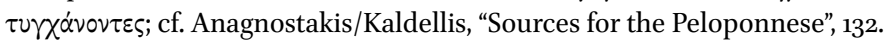

59 See Fögen, "Das politische Denken der Byzantiner", pp. 59-67.

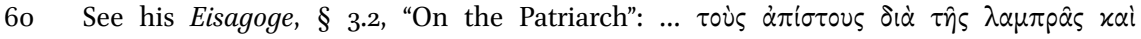

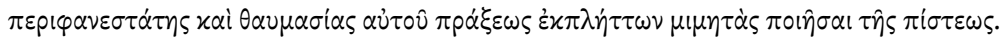




\section{Secondary Literature}

Ahrweiler-Glykatzi, H., "Une inscription méconnue sur les Mélingues du Taygète”, Bulletin de la Correspondance Hellénique 86 (1962), 1-10.

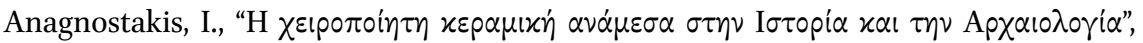

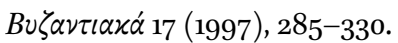

Anagnostakis, I./Kaldellis, A., "The Textual Sources for the Peloponnese, A.D. 582-959: Their Creative Engagement with Ancient Literature", Greek, Roman and Byzantine Studies 54 (2014), 105-35.

Avramea, A., Le Péloponnèse du Ive au viIIe siècle, changements et persistances (Byzantina Sorbonensia 15), Paris 1997.

Bauer, F.A., Eine Stadt und ihr Patron: Thessaloniki und der Heilige Demetrios, Regensburg 2013 .

Beck, H.-G., "Christliche Mission und politische Propaganda im byzantinischen Reich", in La conversione al cristianesimo dell' Europa nell' Alto Medioevo, Atti 140 Sett. st. alto medioevo, Spoleto 1967, pp. 649-676.

Bon, A., La Morée franque. Recherches historiques, topographiques et archéologiques sur la principauté d'Achaie (1205-1430), Paris 1969.

Brandes, W., "Taufe und soziale Inklusion / Exklusion in Byzanz", Rechtsgeschichte 21 (2013), 75-86.

Browning, R., Byzantium and Bulgaria. A comparative study across the early medieval frontier, London 1975.

Brugmann, K./Delbrück, B., Grundriß der vergleichenden Grammatik der indogermanischen Sprachen, I. Einleitung und Lautlehre, Strassburg 1897.

Brunet, F., "Sur l'hellénisation des toponymes slaves en Macédoine byzantine", Travaux et Mémoires 9 (1985), 235-65.

Carlton, T.R., Introduction to the phonological history of the Slavic languages, Columbus, Ohio 1991.

Chrysos, E., "Settlements of Slavs and Byzantine Sovereignty in the Balkans", in K. Belke/E. Kislinger/A. Külzer/M. Stassinopoulou (eds.), Byzantina Mediterranea, Festschrift für Johannes Koder zum 65. Geburtstag, Vienna/Köln/Weimar 2007, pp. 123-135.

Curta, F., The Making of the Slavs, History and Archaeology of the Lower Danube Region, c. 500-700, Cambridge 2001.

Dvorník, F., Byzantine missions among the Slavs: SS. Constantine-Cyril and Methodius, New Brunswick, NJ 1970.

Engelhardt, I., Mission und Politik in Byzanz. Ein Beitrag zur Strukturanalyse byzantinischer Mission zur ZeitJustins und Justinians (Miscellanea Byzantina Monacensia 19), Munich 1974.

Fallmerayer, J.Ph., Geschichte der Halbinsel Morea während des Mittelalters, 1. Untergang der peloponnesischen Hellenen und Wiederbevölkerung des leeren Bodens durch slavische Volksstämme, Stuttgart 1830. 
Fögen, M.Th., "Das politische Denken der Byzantiner", in: I. Fetscher (ed.), Pipers Handbuch der politischen Ideen, 2. Mittelalter, Munich 1993, pp. 41-85.

Georgacas, D.J., Place names of Southwest Peloponnesus, Athens 1967.

Gerov, B., "Die lateinisch-griechische Sprachgrenze", in Die Sprachen im römischen Reich der Kaiserzeit (Bonner Jahrbücher, Beiheft 40), Cologne/Bonn 1980, pp. 147-165.

Grünbart, M., Jakob Philipp Fallmerayer: Bibliographie der Sekundärliteratur, 19oo-2011, Vienna 2011.

Haldon, J.F., A critical commentary on the Taktika of Leo vi (Dumbarton Oaks Studies 44), Washington D.C 2014.

Hannick, Ch., "Die byzantinischen Missionen”, in: Kirchengeschichte als Missionsgeschichte, 2.1. Die Kirche des früheren Mittelalters, Munich 1978, pp. 354-358.

Hardt, M., "Slawen", in M. Borgolte/J. Lemberg (eds.), Migrationen im Mittelalter. Ein Handbuch, Berlin 2014, pp. 171-180.

Henning, J., "Untersuchungen zur Entwicklung der Landwirtschaft in Südosteuropa im Übergang von der Spätantike zum frühen Mittelalter”. Ethnographisch-Archäologische Zeitschrift 25 (1984), 123-30.

Henning, J., "Eisenverarbeitungswerkstätten im unteren Donaugebiet zwischen Spätantike und Frühmittelalter", Zeitschrift für Archäologie 21 (1987), 59-73.

Henning, J., Südosteuropa zwischen Antike und Mittelalter. Archäologische Beiträge zur Landwirtschaft des 1. Jahrtausends u.Z. (Schriften zur Ur- und Frühgeschichte 42), Berlin 1987.

Henrich, G.S., "Einige slawische Siedlungsnamen Nordwestgriechenlands (Nachtrag zu Max Vasmer)", Studia Onomastica 10 (1999), 147-164.

Holzer, G., "Die Einheitlichkeit des Slavischen um 600 n. Chr. und ihr Zerfall", Wiener Slavistisches Jahrbuch 41 (1995), 55-89.

Holzer, G., "Zu Lautgeschichte und Dialekten des mittelalterlichen Slavischen in Österreich", Wiener Slavistisches Jahrbuch 42 (1996), 81-110.

Holzer, G., "Landschaft und Siedlung im slavischen Frühmittelalter", in P. Anreiter/ P. Ernst/I. Hausner/H. Kalb (eds.), Namen, Sprachen und Kulturen / Imena, Jeziki in Kulture. Festschrift für Heinz Dieter Pohl zum 6o. Geburtstag, Vienna 2002, pp. 386-398.

Holzer, G., Historische Grammatik des Kroatischen. Einleitung und Lautgeschichte der Standardsprache, Frankfurt am Main 2007.

Ivanov, S., "Byzantium and the Slavs", in D. Sakel (ed.), Byzantine Culture, Papers from the Conference 'Byzantine Days of Istanbul', Ankara 2014, pp. 207-215.

Izdebski, A., "The Slavs' political institutions and the Byzantine policies (ca 530-650)", Byzantinoslavica 69 (2011), 50-69.

Kislinger, E., Regionalgeschichte als Quellenproblem: Die Chronikvon Monembasia und das sizilianische Demenna. Eine historisch-topographische Studie (Veröff. der Tabula Imperii Byzantini 8), Vienna 2001. 
Koder, J., "Arethas von Kaisareia und die sogenannte Chronik von Monembasia", Jahrbuch der Österreichischen Byzantinistik 25 (1976), 75-80.

Koder, J., "Zur Frage der slavischen Siedlungsgebiete im mittelalterlichen Griechenland", Byzantinische Zeitschrift 71 (1978), 315-31.

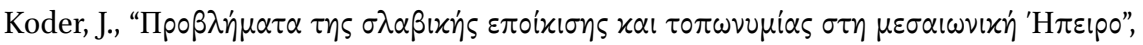
Epeirotika Chronika 24 (1982), 9-35.

Koder, J., "Zu den Archontes der Slaven in De Administrando Imperio 29, 106-115", Wiener Slavist. Jahrbuch 29 (1983), 128-131.

Koder, J., "Anmerkungen zu den Miracula Sancti Demetrii", in Byzance - Hommage à André N. Stratos, 2, Athens 1986, pp. 523-538.

Koder, J., “Sklavinien”, in Lexikon des Mittelalters 7 (1995), p. 1988.

Koder, J., "Nationwerdung und religiöse Identität der Bulgaren", in Kirche und nationale Identität = Mitteilungen des Bulgarischen Forschungsinstitutes in Österreich 12 (1999/200o), pp.9-23.

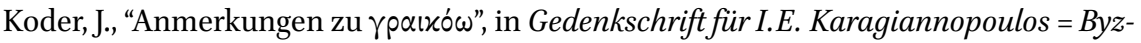
antina 21 (2000), pp. 199-202.

Koder, J., "Anmerkungen zum Slaven-Namen in byzantinischen Quellen", in Mélanges Gilbert Dagron = Travaux et Mémoires 14 (2002), pp. 333-346.

Koder, J., "Bulgarische und byzantinische Identität in der Zeit vor den Kreuzzügen", Thetis 18 (2011), 123-129.

Koder, J., "Illyrikon und Illyrios. Geographische und ethnische Namen der Wortfamilie *illyr in byzantinischen Quellen", in A. Beihammer/B. Krönung/Cl. Ludwig (eds.), Prosopon Rhomaikon. Ergänzende Studien zur Prosopographie der mittelbyzantinischen Zeit, Berlin/Boston 2017, pp. 197-210.

Koder, J., "Anmerkungen zum Awaren-Sgraffito von Sirmium", in J. Drauschke/ E. Kislinger/K. Kühtreiber/Th. Kühtreiber/G. Scharrer-Liška/T. Vida (eds.), Lebenswelten zwischen Archäologie und Geschichte. Festschrift für Falko Daim zu seinem 65. Geburtstag, Mainz 2018, pp. 733-740.

Kresten, O., "Zur Echtheit des sigillion des Kaisers Nikephoros I. für Patras”, Römische Historische Mitteilungen 19 (1977), 17-78.

Kunstmann, H., Die Slaven. Ihr Name, ihre Wanderung nach Europa und die Anfänge der russischen Geschichte in historisch-onomastischer Sicht, Stuttgart 1996.

Lampropoulou, A./Anagnostakis, I./Konti, V./Panopoulou, A., " $\Sigma u \mu \beta 0 \lambda \eta \dot{\eta} \sigma \tau \eta \nu \varepsilon p \mu \eta \nu \varepsilon i ́ \alpha$

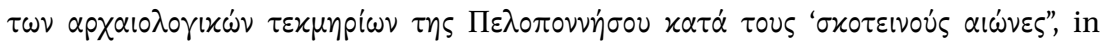

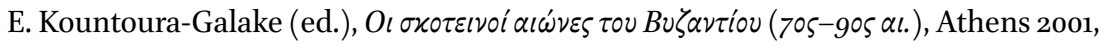
pp. 189-229.

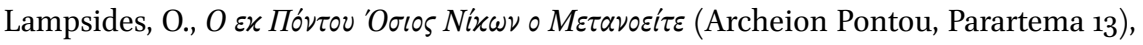
Athens 1982.

Lefort, J., "Toponymie et anthroponymie. Le contact entre Grecs et Slaves en Macédoine", in J. Lefort, Société rurale et histoire du paysage à Byzance (Bilans de Recherche 1), Paris 2006, pp. 265-278. 
Lemerle, P., "L'histoire des Pauliciens d'Asie Mineure d'après les sources grecques", Travaux et Mémoires 5 (1973), 1-113.

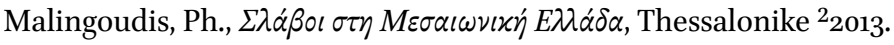

Malingoudis, Ph., Studien zu den slavischen Ortsnamen Griechenlands, Slavische Flurnamen aus der messenischen Mani, Mainz/Wiesbaden 1981.

Manselli, R., "Bogomilen", in Lexikon des Mittelalters 2 (1983), pp. 328-332.

Miklosich, F., Die slavischen Elemente im Neugriechischen, Vienna 1870.

Noll, R., "Ein Ziegel als sprechendes Zeugnis einer historischen Katastrophe (Zum Untergang Sirmiums $5^{82}$ n. Chr.)", in Anzeiger der philosophisch-historischen Klasse der Österreichischen Akademie der Wissenschaften 126 (1989), 139-154.

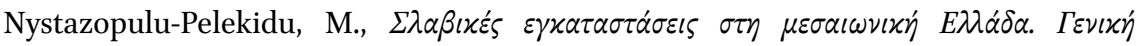

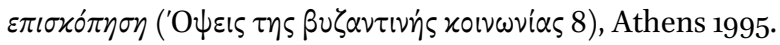

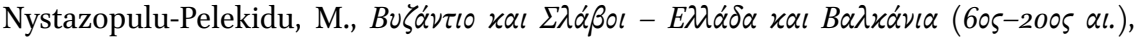
Thessalonike 2001.

Pahlitzsch, J., "Byzanz”, in M. Borgolte/J. Lemberg (eds.), Migrationen im Mittelalter. Ein Handbuch, Berlin 2014, pp. 93-106.

Pohl, W., Die Awaren, ein Steppenvolk in Mitteleuropa 567-822 n. Chr., Munich $2_{2002 .}$

Schramm, G., Eroberer und Eingesessene. Geografische Lehnnamen als Zeugen der Geschichte Südosteuropas im ersten Jahrtausend $n$. Chr., Stuttgart 1981.

Pohl, W., Ein Damm bricht. Die römische Donaugrenze und die Invasion des 5.-7. Jahrhunderts im Lichte von Namen und Wörtern, München 1997.

Pohl, W., "Ortsnamen und Lehnwörter als Quellen der Frühgeschichte Osteuropas", Zeitschrift für Balkanologie 37 (2001), 62-83.

Pohl, W., "Note sur la fondation de Monemvasie en $582-583$ ", Travaux et Mémoires 4 (1970), 471-75.

Schreiner, P., "An den Anfängen einer geschichtlichen Darstellung des Byzantinischen Reiches. Mit unedierten Scripten Fallmerayers aus der Nachlass-Sammlung der Bayerischen Staatsbibliothek im Anhang", in C. Märtl/P. Schreiner (eds.), Jakob Philipp Fallmerayer (1790-1861). Der Gelehrte und seine Aktualität im 21. Jahrhundert (Abhandlungen der philosophisch-historischen Klasse der Bayrischen Akademie der Wissenschaften, NF 139), Munich 2013, pp. 33-161.

Shevelov, G.Y., A Prehistory of Slavic. The Historical Phonology of Common Slavic, Heidelberg 1964.

Skach, E., Die Lautgeschichte des frühen Slavischen in Griechenland im Lichte der Lehnbeziehungen, Vienna 2008.

Soustal, P., Nikopolis und Kephallenia (Tabula Imperii Byzantini 3), Vienna 1981.

Soustal, P., "Überlegungen zur Rolle der Toponyme in der historischen Geographie”, in Byzanz als Raum. Zu Methoden und Inhalten der historischen Geographie des östlichen Mittelmeerraumes (Veröffentlichungen der Kommission für die Tabula Imperii Byzantini 7), Vienna 2000, pp. 209-221. 
Soustal, P., "Place names as a source for migration and settlement: continuity and change in Byzantine Chalkidiki", Wiener Schriften zur Geographie und Kartographie, 18 (2009), 177-183.

Soustal, P., "Überlegungen zu Toponymen der Region Kastoria aus dem osmanischen Defter von 1440", in B. Krsmanović/Sr. Pirivatrić (eds.), Mélanges Ljubomir Maksimović = Zbornik Radova Vizantološkog Instituta 50.1-2 (2013), pp. 863-871.

Soustal, P., "Zur Präsenz der Slawen auf dem Heiligen Berg Athos", in A. Schwarcz/ P. Soustal/A. Tcholakova (eds.), Das mittelalterliche Bulgarien, Byzanz und Europa. Festschrift für Vasil Gjuzelev zum 75. Geburtstag = Miscellanea Bulgarica 21, Vienna 2014, pp. 77-88.

Stavridou-Zafraka, A., "Slav Invasions and the Theme Organization in the Balkan Peninsula", Byzantiaka 12 (1992), 165-179.

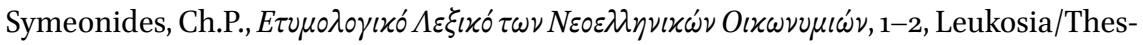
salonike 2010.

Thesaurus Linguae Graecae. A Digital Library of Greek Literature, Irvine, California 2001, online: http://stephanus.tlg.uci.edu.

Trapp, E., et al., Lexikon zur byzantinischen Gräzität, besonders des 9.-12. Jahrhunderts, Vienna 2001-2017.

Vasmer, M., Die Slaven in Griechenland, Berlin 1941.

Waldmüller, L., Die ersten Begegnungen der Slawen mit dem Christentum und den christlichen Völkern vom VI. bis VIII. Jahrhundert. Die Slawen zwischen Byzanz und Abendland, Amsterdam 1976.

Weiss, G., Das Ethnikon Sklabenoi, Sklaboi in den griechischen Quellen bis 1025 (Glossar zur frühmittelalterlichen Geschichte im östlichen Europa, Beiheft 5), Stuttgart 1988.

Zaimov, J., Zaselvane na bălgarskite Slavjani na Balkanskija poluostrov: proučvane na žitelskite imena $v$ bălgarskata toponimija, Sofia 1967. 